\title{
Maternidade negra em Um defeito de cor: a representação literária como disrupção do nacionalismo
}

\author{
Fabiana Carneiro da Silva ${ }^{1}$
}

\section{"Mãe preta": o signo de uma interdição}

Ainda que esteja presente no corpus da literatura brasileira de modo explícito e reiterado e que tenha passado a constituir um número considerável de estudos, sobretudo no universo das ciências humanas, tais como história e antropologia, a figura da "mãe preta", até recentemente, não recebeu a devida atenção da crítica literária, conforme sublinha Sônia Roncador, que, a partir da teoria literária, propôs-se a delimitar esse estudo (2008, p. 129-152). Somando-se ao estereótipo da "mulata", a "mãe preta" configura a outra forma com que a mulher negra foi principalmente representada pela literatura alçada à condição de nacional no Brasil. Em ambas as representações, tolhe-se a possibilidade de que essa mulher seja representada subjetivamente enquanto mãe, na medida em que, num dos casos ela é estéril (conforme indica o termo "multa", do qual deriva "mulata", que se refere à espécie resultante do cruzamento entre um cavalo e um jumento) e, no outro, sua relação com o próprio filho é invisibilizada. Ainda, a inserção do elemento "preta" como caracterizador da ideia (tão essencializada) de "mãe" demarca com intensidade a racialização e a posição subalterna atribuída à mulher negra, formalizando, como veremos a seguir, um sistema em que a justaposição dos dois termos gera um curtocircuito semântico.

A mãe preta estabelece correspondência com a figura que, no contexto literário, cinematográfico e midiático estadunidense fixou-se como mammy, isto é, a representação da trabalhadora negra doméstica que, em consonância com a explicação de Roncador (2008), sendo escravizada ou liberta, é destituída da relação com seus próprios filhos e passa a cuidar e amamentar os filhos das famílias senhoriais brancas. Tal como indicado por Kimberly Wallace-Sanders (2008, p. 18), em análise baseada sobretudo em significativos romances do século XIX nos Estados Unidos, a mammy é caracterizada como uma mulher de pele preta (remetida à

\footnotetext{
${ }^{1}$ Doutoranda em teoria literária e literatura comparada na Universidade de São Paulo (USP), São Paulo, SP, Brasil. Dorcid.org/0000-0001-5986-4389. E-mail: fabicarneirodasilva@yahoo.com.br
} 
África enquanto forma de marcar distanciamento do fenótipo vinculado à miscigenação), enérgica, com autoridade respeitada pela crianças de quem cuida, solitária e atrelada ao sentimento de tristeza e dor.

No âmbito da literatura canônica brasileira, de acordo com Roncador (2008), a "mãe preta" é alçada à condição de mito, no qual aparece como símbolo da "fidelidade incondicional" e do "servilismo absoluto à classe senhorial"; uma mulher que, "apesar de lhe ter sido retirado o filho, ama e acolhe com doçura a criança branca a que deverá amamentar". Nesse contínuo, de modo análogo à figura da mammy, a mãe preta poderia ser descrita nos termos desse mito como aquela que ama os filhos dos brancos mais do que os próprios filhos:

Essa caracterização inicial estabelece a base problemática para o enigma da maternidade da mammy: seu amor por seus encargos se torna mais sublime, mais extraordinário quando suplanta seu amor por sua própria carne e sangue, filhos que pertencem a seu mestre ou, às vezes, aos próprios jovens pelos quais é responsável (Wallace-Sanders, 2008, p. 18, tradução nossa).

Além de Sônia Roncador (2008), como uma das escassas fontes disponíveis acerca dessa representação na literatura brasileira, destacase a pesquisa de Rafaela de Andrade Deiab (2006), que, a partir da antropologia social, produziu a dissertação intitulada $A$ mãe-preta na literatura brasileira: a ambiguidade como construção social (1880-1950). Em seu trabalho, Deiab analisa a representação social das mães pretas na literatura produzida no Brasil no período pós-abolição. A pesquisa que, de acordo com ela, foi desenvolvida preocupando-se "menos com uma suposta 'realidade histórica' das escravas domésticas e amas-deleite, do que com as versões que essa memória da 'mãe preta' permite veicular" - delimita e evidencia a ambiguidade com que as amas de leite foram incorporadas às obras literárias apresentadas, sendo que, na maioria das vezes, "o processo de construção dessa memória implic[ou] em uma seleção que reelabor[ou] determinadas imagens (permeadas por afetividade, santidade, gratidão) em detrimento de outras (que evocam violência, conflito)" (Deiab, 2006, p. 24-25).

Apesar de não realizar uma análise detida dos textos literários propriamente ditos, Deiab faz um levantamento significativo das referências a mães pretas presentes em autores que publicaram no Brasil entre 1880 e 1950, incluindo aí textos integrantes da literatura infantil. Tem-se, então, um mapeamento de como, no transcorrer do 
tempo, a imagem da escravizada ou liberta que amamenta o filho branco dos (ex)escravizadores se modifica (inclusive nas formas de representação fotográfica) de modo a acompanhar o processo de modernização do país e, com ele, o desejo de apagamento do recente passado escravista. Nessa direção, a imagem da mãe preta, configurada a partir da oposição com a imagem do filho branco, vai sendo ajustada ao projeto estatal de construção de uma identidade nacional mestiça, que, por mais que se enraíze na vexatória estrutura escravagista colonial, continua a ser evocada e reelaborada.

Em consonância com isso, a presença das amas de leite na produção literária do período - e, como veremos, também em parte do século XX - surge como uma forma de acomodação de conflitos e de estabelecimento, por meio da ênfase no afeto da "mãe preta" pelo filho de seu "senhor", de um precário equilíbrio entre posições tão arbitrariamente desiguais. Deiab sustenta, assim, a hipótese de que "seja como memória oficial, seja como memória popular ou do senso comum, ela (a figura da 'mãe preta') permite fazer as pazes com recente passado escravocrata que, se não podia ser esquecido, podia ao menos ser lembrado em sua faceta mais íntima, afetiva e também dilacerante" (2006, p. 24). No aprofundamento da análise dessas representações, o trabalho de Deiab (2006) mostra como, para os escritores pesquisados, a positividade da representação literária da mãe preta vinculou-se ao sentimento de perda, lamentosa, de uma tradição cultuada por eles e que tinha essa figura como representante.

Em seu trabalho, já citado aqui, Roncador (2008) faz avaliação em sentido semelhante. De acordo com a autora, depois de um certo declínio, a mãe preta se popularizou como personagem, principalmente nas memórias de infância de escritores modernistas publicadas entre as décadas de 1930 e 1960. Além de em Gilberto Freyre e José Lins do Rego, também citados por Deiab, constata-se sua presença em textos de Carlos Drummond de Andrade e José Américo de Almeida, todos com publicações nas quais se encontram mães negras rememoradas, segundo Roncador (2008), como elemento que remete à nostalgia de uma tradição aristocrática em decadência. Em vez, portanto, do antagonismo entre a família senhorial (incluindo como elemento significativo as brancas escravizadoras a quem são conferidos os atributos de pureza, castidade e maternidade) e escravas/libertas (interditadas de exercerem sua própria maternidade e, de modo correlato, de constituírem sua família), o que se 
produz em termos simbólicos no imaginário da época é a imagem da conciliação e do carinho, ${ }^{2}$ ou, nos termos de Roncador, uma "utopia da confraternização das duas raças" (2008, p. 134).

É dessa forma que o fato de a mulher negra ter tido a família branca como um espaço de exercício de sua maternidade ao longo do século XIX não é problematizado pela literatura organizada em torno do projeto de construção nacional, que, ao contrário disso, reforça simbolicamente a obstrução da possibilidade de as mulheres negras constituírem seus próprios laços afetivos e reprodutivos. ${ }^{3}$ Sendo assim, as representações que buscaram literariamente configurar a prática da amamentação mercenária, na qual afeto e violência estabelecem interdependência, instituíram-na de uma conotação positiva, revelando-se parciais e mitificadoras. ${ }^{4}$

2 De modo correlato, Wallace-Sanders mostra como, nos Estados Unidos, na relação com as crianças brancas, a mammy é representada de modo idealizado, na figura da condutora de um amor sublime, enquanto na relação com suas próprias crianças ela é instintiva, grosseira e selvagem (Wallace-Sanders, 2008).

${ }^{3}$ A perversidade dessa dinâmica é explicitada contundentemente por Lélia Gonzalez, que no texto "Racismo e sexismo na cultura brasileira" discute a figura da mulata e da mãe preta atribuindo a esta, porém, o potencial de "passar uma rasteira na classe dominante". Segundo Gonzales, os problemas das formas de representação da mãe preta não são suficientes para neutralizar o fato, contido nesse estereótipo, de que na cultura brasileira é a mulher negra quem de fato exerce o papel de mãe: "Exatamente essa figura para a qual se dá uma colher de chá é quem vai dar a rasteira na raça dominante. É através dela que o 'obscuro objeto do desejo' (o filme do Buñuel), em português, acaba se transformando na 'negra vontade de comer carne' na boca da moçada branca que fala português. O que a gente quer dizer é que ela não é esse exemplo extraordinário de amor e dedicação totais como querem os brancos e nem tampouco essa entreguista, essa traidora da raça como querem alguns negros muito apressados em seu julgamento. Ela, simplesmente, é a mãe. É isso mesmo, é a mãe. Porque a branca, na verdade, é a outra. Se assim não é, a gente pergunta: quem é que amamenta, que dá banho, que limpa cocô, que põe pra dormir, que acorda de noite pra cuidar, que ensina a falar, que conta história e por aí afora? É a mãe, não é? Pois então. Ela é a mãe nesse barato doido da cultura brasileira. Enquanto mucama, é a mulher; então 'bá', é a mãe. A branca, a chamada legítima esposa, é justamente a outra que, por impossível que pareça, só serve pra parir os filhos do senhor. Não exerce a função materna. Esta é efetuada pela negra. Por isso a 'mãe preta' é a mãe" (Gonzalez, 1984, p. 235). A sagaz inversão realizada por Gonzalez busca tirar o recalque da experiência como mãe que também integra o repertório das mulheres que se viram impelidas ao trabalho com os filhos de outrem (e ainda veem-se, como ela demonstra, no caso das babás e outras trabalhadoras domésticas). Porém, essas experiências, retidas nas diversas e conflituosas narrativas literárias, não podem se perfazer sem a consideração do alheamento entre mãe negra e filho negro tão agressivamente expressa na imagem da mãe preta. O que há de dor e violência nesse estereótipo, bem como tudo aquilo que o excede e aponta para outras múltiplas formas de exercício da maternidade pelas mulheres negras, encontra eco num conjunto de obras literárias produzidas a partir de uma complexa perspectiva interna negra que, contudo, permaneceram invisibilizadas ou às margens do cânone.

${ }^{4}$ Por uma perspectiva elaborada pela história social da escravidão, acompanhamos como as amas de leite foram primeiramente destituídas da relação com o próprio filho e, depois, já num processo de construção do discurso racialista brasileiro, também afastadas da relação com a criança branca. 
Conceição Evaristo (2005) foi quem contemporaneamente chamou atenção para a quase ausência da representação da maternidade da mulher negra no campo literário do país ${ }^{5}$ e, reiterando o argumento desenvolvido até aqui, escreveu: "Quanto à mãe preta, aquela que causa comiseração ao poeta, cuida dos filhos dos brancos em detrimento dos seus. Mata-se no discurso literário a sua prole, ou melhor, na ficção elas surgem como mulheres infecundas e portanto perigosas" (Evaristo, 2005, p. 2). Nesse contínuo, Evaristo salienta e aprofunda a reflexão que tem como núcleo os vínculos entre um projeto nacional excludente e a literatura:

A representação literária da mulher negra, ainda ancorada nas imagens de seu passado escravo, de corpo-procriação e/ou corpoobjeto de prazer do macho senhor, não desenha para ela a imagem de mulher-mãe, perfil desenhado para as mulheres brancas em geral. Personagens negras como Rita Baiana, Gabriela, e outras não são construídas como mulheres que geram descendência. Observando que o imaginário sobre a mulher na cultura ocidental constrói-se na dialética do bem e do mal, do anjo e demônio, cujas figuras símbolos são Eva e Maria, e que o corpo da mulher se salva pela maternidade, a ausência de tal representação para a mulher negra acaba por fixar a mulher negra no lugar de um mal não redimido (Evaristo, 2005, p. 2).

A contundência das asserções de Evaristo - somadas à tessitura conceitual que sinteticamente (re)constrói-se aqui - reverberam na produção literária contemporânea, sobretudo naquela produzida sob a rubrica da literatura negra, e abrem caminho para a elaboração das hipóteses apresentadas neste artigo. A discursividade resultante do encontro das narrativas canônicas evocadas ratifica que o corpo da mulher negra, quando mãe, é lido nessas obras como corpo-força-detrabalho, na medida em que a capacidade geradora da mulher negra é afirmada, mas negada simultaneamente no gesto de interdição da relação dela com seus próprios filhos. Um defeito de cor, conforme veremos, opera um giro crítico nessa lógica de representação ao encená-

\footnotetext{
${ }^{5}$ Isso não significa que não haja representações da maternidade sob a perspectiva da mulher negra. Maria Firmina dos Reis, ainda no contexto escravista do século XIX, transfigurou literariamente essa experiência (a qual aparece de modo contundente no conto "A escrava" de 1887), que também figura, já em meados do século XX, por exemplo, na obra de Carolina Maria de Jesus, como em Quarto de despejo de 1960, ou de Anajá Caetano, que em 1966 publica Negra Efigênia, paixão do senhor branco. Com o fortalecimento da produção literária de mulheres negras nas últimas décadas, a própria Conceição Evaristo constitui referência de autoria de uma série de personagens que são mães negras e lidam de formas diversas com o evento da maternidade.
} 
la, tendo, porém, a fertilidade da mulher negra como um fato assumido e o desaparecimento de seus filhos como um problema central.

\section{Kehinde: mãe de Banjokô, Omotunde, João e Maria Clara}

Um defeito de cor provocou impacto no momento de seu lançamento. Foi resenhado por Millôr Fernandes e Idelber Avelar e recebeu o prêmio "Casa de las Américas" em 2011. Passados 11 anos desde que veio a público, já acumulou uma fortuna crítica considerável. Entre as publicações sobre o romance, destacam-se, sobretudo, leituras que, além de discutirem o gênero da obra, delimitam sua análise sobre temas que recorrentemente são vinculados às questões da diáspora negra, tais como memória transatlântica, resiliência, identidade e consciência intelectual negra. ${ }^{6}$ A questão da maternidade não instigou o interesse da crítica até o surgimento, em 2014, da tese No colo das iabás: raça e gênero em escritoras afro-brasileiras contemporâneas, de Vania Maria Ferreira de Vasconcelos.

Nesse trabalho, Vasconcelos tem a maternidade como fio condutor, o qual permite que ela debruce sua análise sobre a obra de Ana Maria Gonçalves, assim como de Conceição Evaristo, além de contos de outras autoras (cujo principal suporte de publicação foram os Cadernos Negros) identificadas como "afro-brasileiras". No intuito de desenvolver uma reflexão feminista sobre as formas como gênero e raça são construídos nessas escritas, Vasconcelos entende ser a "maternidade" uma potente chave de leitura na medida em que:

o tema está presente na ficção e poesia das autoras afrodescendentes, negando a lógica patriarcal de dominação que buscou construir uma imagem dessas mulheres sempre distante da figura materna, como produtos úteis à fantasia sexual masculina. As novas representações, trazidas mais e mais pelas escritoras, vão construindo outros sentidos, distantes dos antigos estereótipos, a partir de perspectivas que partem da experiência de mulheres que tem buscado desde as primeiras ações feministas, apropriarem-se daquilo que se diz sobre elas mesmas (Vasconcelos, 2014, p. 181).

Resguardando o fato de que o procedimento de "leitura feminista" no que se refere a Um defeito de cor, tal como operado por

\footnotetext{
${ }^{6}$ Algumas dessas obras são Duarte (2009), Gonçalves (2010), Bernd (2012), Figueiredo (2009), Cortês (2010) e Lange (2008).
} 
Vasconcelos, possa ser problematizado (e farei isso adiante), sua sagaz identificação da maternidade como elemento central da obra repercute em consonância com minha hipótese de leitura, de modo que parece imprescindível a afirmação formulada por ela, segundo a qual no romance:

A ideia de reunir toda a memória do que viveu para deixar ao filho é a razão que a leva a reconstruir o que provavelmente foi a experiência de muitos africanos que viveram nas principais cidades brasileiras do século XIX. Esse povo está representado nas agonias e vitórias de Kehinde. Por outro lado, ao escrever uma narrativa na qual uma mãe busca deixar registro de sua vida para o filho, Gonçalves constrói uma protagonista de caráter peculiar, uma mulher que, apesar da experiência da escravidão, coloca-se como centro da história, insiste em narrar a si mesma, não permitindo que ninguém conte a história que é dela (Vasconcelos, 2014, p. 172).

A despeito dos outros sentidos que podem ser depreendidos do relato e das múltiplas facetas que Kehinde assume ao longo do enredo - entre elas, mulher africana, escravizada, negra de tabuleiro, revolucionária atuante na Rebelião do Malês, liberta, vodunsi, vendedora de armas, empresária no setor da construção civil e até mesmo mulher capaz de matar para defender sua vida -, uma leitura atenta à narração reconhece que é a necessidade de comunicação com o filho e a redenção da culpa sentida pela separação entre ambos que motiva o surgimento do texto. Esse dado é explicitado nas últimas páginas do romance:

Andei muito doente nos últimos três anos, e só não morri porque o encontro já estava marcado para daqui a pouco, assim que eu terminar esse meu pedido de desculpas. Porque é assim que vejo tudo isso, como um grande mea-culpa. Muito maior do que o pedido ao João, à Maria Clara, ao genro, às noras e a todos os netos que foram se despedir de mim no porto de Lagos, onde eu e a Geninha tomamos este navio. Tentaram me convencer a ficar, argumentando que eu não aguentaria a viagem, que não teria como te encontrar e nem sabia se você ainda estava vivo ou morando no mesmo lugar, em São Paulo. Mas nada disso teve importância, pois eu tinha a certeza de que precisava vir, precisava te contar tudo que estou contando agora. Se vai chegar às suas mãos, também não sei [...]. Se alguém vai contá-la a alguém qualquer dia desses eu não sei, mas fiz o que tinha que ser feito (Gonçalves, 2006, p. 945). 
Na esteira do que desenvolvemos até aqui, em aliança com o que declara a narradora, a delimitação de Vasconcelos (2014) é precisa e contribui para que notemos como a representação de Kehinde distanciase tanto da figura da "mulata" quanto da "mãe preta" que marcaram a presença da mulher negra no cânone da literatura brasileira. Ao caracterizar a si mesma, na narração ficcional, Kehinde descreve uma mulher de pele preta que, entre outros fatores, é detentora da capacidade de concepção, expressa no ato de dar à luz a quatro filhos: Banjokô, Omotunde (ou Luiz), João e Maria Clara.

Vasconcelos (2014) também flagra isso e, objetivando a interpretação de Um defeito de cor, concebe o romance como uma "história do possível" (tomando o termo de empréstimo de Tânia Swain), delimitando o vínculo entre Kehinde e as outras personagens femininas presentes na narrativa, particularmente com mulheres de sua linhagem familiar, a fim de visibilizá-las e analisar os possíveis significados que sua representação condensa. Nessa direção, navega por águas que recuperam o arquétipo da mãe no Ocidente e tenta contrapô-lo às noções de maternidade africanas presentes nas escritas de autoria feminina negra. No entanto, apesar de esboçar o mesmo gesto crítico no que se refere à matização do postulado "feminismo", em determinados momentos, seu trabalho parece perder de vista a tensão que problematiza as essencializações basilares de certas categorias teóricas utilizadas e acaba por aproximar a obra de um espectro conceitual que exigiria mediações mais desenvolvidas. É esse procedimento que pode ser constatado em estamentos como:

Podemos também observar que Kehinde é construída sob uma perspectiva feminista por parte da autora, porque a personagem não se deixa dominar por homens, depois de liberta e, mesmo quando apaixonada, não abandona seus objetivos ou abre mão da independência financeira, por exemplo. Consideramos importante o fato da autora ter escolhido para sua personagem uma família formada por mãe e avó, mulheres fortes e independentes, sem nenhum homem que lhes questionasse as decisões. Esta característica é também importante na forma como vivencia suas experiências maternais (Vasconcelos, 2014, p. 182).

A diferença histórica entre a condição das mulheres brancas e das mulheres negras, assim como entre os processos de emancipação de tais grupos que, apesar da divergência em relação a muitas pautas, uniramse estrategicamente - diferença essa magistralmente desenvolvida, no 
que se refere ao contexto estadunidense, por Angela Davis (2016) ${ }^{7}$ mesmo que mencionada, não tem sustentada na tese a relevância que possui para o universo das "escrivivências" 8 das mulheres negras. Desse modo, ainda que busque deslocar os referenciais eurocêntricos, evocando a cosmovisão iorubana, no texto, resulta frágil o procedimento que estabelece conexão entre os postulados feministas e o universo mitológico dos orixás a fim de operar uma transposição deles às caracterizações das personagens do romance. Nesse sentido, sem deixar de ratificar que a tese se trata de uma leitura substancial da obra de Gonçalves e detém o mérito da identificação da maternidade como chave de leitura do livro, nossas águas seguem cursos distintos.

A referência às amas de leite recebe pouco investimento de análise no trabalho de Vasconcelos (2014), mas, a meu ver, é fundamental, enquanto figura contrastiva ligada ao discurso da nacionalidade, para a compreensão de como Um defeito de cor, ao encenar a fala de uma mãe, desafia as formas - racistas - de controle da imagem da mulher negra na literatura. Ana Maria Gonçalves (2006) mergulha nas contradições da maternidade negra no século XIX e produz um romance que trata, entre outras coisas, da luta da mulher negra por exercer essa maternidade (encarando os temas correlatos a isso, como omissão e o abandono masculinos, a discriminação, a solidão e a culpa). A trajetória de vida da narradora e sua forma particular de contá-la, a uma só vez, recupera e desmonta a lógica do corpo da mulher negra como reprodutor do filho

\footnotetext{
${ }^{7}$ Davis identifica uma ideologia da "feminilidade" que surge com a industrialização no século XIX e afasta cada vez mais a mulher branca da esfera do mundo do trabalho produtivo. Mulher (branca) torna-se, segundo ela, sinônimo de "mãe" e "dona de casa". Contudo, isso não se aplica às mulheres negras, já que: "A exaltação ideológica da maternidade - tão popular no século XIX - não se estendia às escravas. Na verdade, aos olhos de seus proprietários, elas não eram realmente mães; eram apenas instrumentos que garantiriam a ampliação da força de trabalho escrava. Elas eram 'reprodutoras' - animais cujo valor monetário podia ser calculado com precisão a partir de sua capacidade de se multiplicar" (Davis, 2016, p. 19). Sendo assim, a autora mostra como houve uma diferença na incorporação dos papéis sexuais (assim como na relação homem-mulher) dentro dessa nova ideologia, a qual teve desdobramentos ulteriores. De modo a não deixar dúvidas disso, ela afirma ainda: "Embora tenham colaborado de forma inestimável para a campanha antiescravagista, as mulheres brancas quase nunca conseguiram compreender a complexidade da situação da mulher escrava. As mulheres negras eram mulheres de fato, mas suas vivências durante a escravidão trabalho pesado ao lado de seus companheiros, igualdade no interior da família, resistência, açoitamentos e estupros - as encorajavam a desenvolver certos traços de personalidade que as diferenciavam da maioria das mulheres brancas" (Davis, 2016, p.39).

${ }^{8}$ Conceito de Conceição Evaristo que procura vincular a escrita de mulheres negras às suas experiências histórico-sociais no Brasil.
} 
ausente (ou apagado/ subtraído/assassinado) que vimos caracterizar a representação da "mãe preta".

É isso que podemos constatar se nos detivermos na forma como se dá a relação da narradora com cada um de seus filhos. O primogênito, Banjokô, é fruto do estupro de Kehinde, ainda em condição de escrava, pelo seu então escravizador, José Carlos. Numa das passagens mais violentas da obra, ela narra esse estupro como uma experiência de morte que finda somente meses depois, com a percepção dos movimentos de Banjokô em sua barriga:

Eu queria morrer, mas continuava mais viva que nunca, sentindo a dor do corte na boca, o peso do corpo do sinhô José Carlos sobre o meu e os movimentos do membro dele dentro da minha racha, que mais pareciam chibatadas. Eu queria morrer e sair sorrindo, dançando e cantando, como minha mãe tinha feito [...]. De todo o resto que aconteceu depois, só tomei consciência quatro ou cinco meses mais tarde, quando meu filho começou a mexer dentro da minha barriga. Foi só na hora em que ele se mexeu que entendi que estava viva e queria continuar viva. Se não por mim, pelo menos por ele, a quem imediatamente comecei a chamar de Banjokô, "sente-se e fique comigo", para prevenir caso fosse um abiku, como eu já pressentia (Gonçalves, 2006, p. 171-173).

A analogia entre a penetração do pênis do sinhô e as chibatadas escancaram com a força da imagem literária a vulnerabilidade do corpo da mulher negra nesse período. Com a mesma habilidade formal, o desdobramento do episódio - que tem como agravante o estupro e a mutilação também de Lourenço, então companheiro de Kehinde correlaciona o estupro à possibilidade de concepção de uma nova vida, a mesma que perversamente retira a narradora do estado de torpor e é lida por ela como um novo sentido de existência.

É na gestação dessa criança e nos anos subsequentes a seu nascimento que o leitor pode acompanhar em detalhes as primeiras constrições à maternidade experienciadas por Kehinde. ${ }^{9}$ Banjokô nasce no porto de Salvador quando da chegada de Kehinde em companhia de sua "sinhá", já viúva, Ana Felipa Dusseldorf Albuquerque de Almeida Carvalho Gama. Essa senhora, caracterizada como uma mulher cruel e

\footnotetext{
${ }^{9}$ Não esquecendo que ela já havia perdido a mãe e a avó. Esta não tendo suportado a viagem a bordo do tumbeiro e aquela assassinada em África diante dos filhos em passagem que abre a narrativa.
} 
amarga, por ter sofrido sucessivos abortos e não ter conseguido dar à luz a um filho daquele que, via estupro, engravidou Kehinde, aproveitase de seu poder de propriedade sobre o bebê e aproxima-se dele, buscando exercer a desejada maternidade. Simultaneamente, passa a usar os recursos de que dispõe para afastá-lo de sua mãe; o primeiro recurso é a locação de Kehinde a uma família inglesa; o segundo, a indicação de que ela trabalhe como escrava de ganho e, assim, permaneça o maior tempo possível afastada da casa senhorial.

Kehinde é, dessa maneira, coagida a acompanhar o crescimento de Banjokô no "seio de uma família branca", isto é, recebendo a educação e afetos daquela que lhe oprime e agride, moral e fisicamente. ${ }^{10}$ A situação da narradora é dramaticamente intensificada pelo dado de que, enquanto escravo, Banjokô poderia ter uma vida muito mais dura sem a proteção da sinhá, sendo vendido ou submetido ao trabalho infantil; essa mesma proteção implicava, contudo, o afastamento daquela que teria o direito sobre sua criação. Desse modo, nas passagens em que essa interdição é narrada, evidencia-se a hierarquização existente entre as experiências de mulheres brancas e negras no século XIX no Brasil e enfatiza-se a dificuldade dolorosa da mãe negra ao se ver apartada de seu bebê.

No entanto, a potência dessa representação não se esgota aí. Se acompanharmos o desdobramento da narrativa dessa etapa da vida de Kehinde e aprofundarmos sua análise, constatamos que o romance encena as restrições à dimensão materna da narradora, mas, simultaneamente, realiza uma inversão na lógica que vimos ser recorrente na caracterização das mulheres negras como mães na literatura. Desse modo, é significativo que Kehinde, sendo mãe, não é forçada ao trabalho como ama de leite. A autora recupera a imagem que discutimos aqui para apresentá-la (desde uma descrição que parece retomar a caricatura da mammy) e em seguida, ressignificá-la:

Nos três primeiros dias eu não consegui amamentar o Banjokô, pois meu peito estava seco, e tive medo que ele se apegasse demais à ama de leite que a sinhá arrumou, a Joana, escrava de uma vizinha. Ela era uma preta gorda e de cara lisa e risonha, a pele

\footnotetext{
${ }^{10}$ Em uma das vezes que Kehinde sai às escondidas com Banjokô e é descoberta por Ana Felipe, a reação da senhora é violenta: "Ela gritou para que a Esméria pegasse o menino e me arrastou pelos cabelos até a varanda, dizendo que além de insolente eu era irresponsável [...]. Quando chegamos à varanda, ela começou a me dar tapas no rosto, com uma força que nunca imaginei que tivesse" (Gonçalves, 2006, p. 210).
} 
sempre brilhando, o cabelo esticado para cima e preso com uma tira de pano bem no alto da cabeça, parecido com um pompom, como os que a sinhá usava para empoar o rosto. A Joana tinha dado à luz havia mais de três anos e o filho tinha morrido com dias de vida, mas o leite dela nunca chegou a secar, pois estava sempre dando o peito. Ela quase não pôde ficar com o Banjokô, porque na época já amamentava três crianças, filhos de sinhás, mas a pedido da sinhá Ana Felipa à sinhá dela, e com a promessa de que nenhuma das mães brancas ficaria sabendo que ela estava amamentando um preto, o acordo foi feito, não sei se envolvendo algum dinheiro. $\grave{A}$ noite sozinha com o meu filho, a Esméria me orientava a colocá-lo no peito, mesmo que não saísse nada. E foi assim que fiz, sendo que certo dia o leite brotou (Gonçalves, 2006, p. 190, grifo nosso).

A partir do momento em que passa a produzir leite, Kehinde amamenta seu próprio filho e, numa construção de grande força simbólica, é a sinhá quem aparece na narrativa marcada pela esterilidade. ${ }^{11} \mathrm{O}$ lugar da falta e da impotência é, assim, transferido para Ana Felipa, como podemos ver no seguinte trecho que narra, como patético, o desespero dela por ser mãe:

Depois, com a justificativa de que ele [Banjokô] poderia atrapalhar nosso serviço, [a sinhá] começou a pedir à Antônia que o levasse para o quarto dela, onde fechava a porta e dizia que precisava descansar, que não queria ser incomodada. Esquecendo-se disso, a Antônia uma vez entrou no quarto e a viu sentada na poltrona com ele no colo. $A$ poltrona ficava de costas para a porta, mas ela teve quase certeza de que sinhá estava tentando dar o peito a ele, que resmungava baixinho e se calava quando ela começava a cantar (Gonçalves, 2006, p. 191).

A cena em que Ana Felipa tenta dar o peito - que não produz leite ao bebê, que a rejeita, volve em frágil o papel da mulher branca construído pelo ocidente de modo idealizado como a posição da plenitude. A forma como a relação entre "mulher negra" e "mulher branca" é acionada no mito da "mãe preta", nesse caso, é deslocada.

\footnotetext{
${ }^{11}$ No momento futuro da narrativa, Kehinde revela que os sucessivos abortos de Ana Felipa deviam-se a ações dos escravizados que, como forma de vingança pelos maus-tratos sofridos, colocavam elementos abortivos na comida dela. Essa versão que matiza a ideia de esterilidade, não deixa de ser significativa no sentido que sublinha a agência negra (e desmente a condição dócil e servil com que a população escravizada foi descrita em alguns textos de referência sobre o período) e ratifica a caracterização da sinhá como aquela que não pode ter filhos.
} 
Outra dimensão relevante na caracterização dessa narradora é o dado de que ela não deixa de expressar os seus desejos, tanto enquanto amante, na relação que mantém com Francisco, quanto como estudiosa, tendo em vista a leitura cada vez mais voraz dos livros que ela encontra na casa do padre Heinz (aquele que cede espaço para a produção do seu produto de ganho). Delineia-se uma subjetividade que apresenta movimentos autorreflexivos profundos e, entre eles, o sentimento de culpa pela impossibilidade de dedicação integral a Banjokô, que convive com uma consciência preocupada com a sobrevivência e, nesse sentido, atenta às oportunidades do momento.

Esse sentimento apresenta-se crescente ao longo da narrativa e dá mostras de uma focalização da maternidade negra que acolhe suas contradições e, assim, afasta-se da idealização ou do essencialismo. Isso sublinha a distância da forma como Kehinde se caracteriza e uma mirada vitimizadora ou, como vimos ser traço ligado ao mito das "mães pretas", da prevalência dos sentimentos de dor e sofrimento que compõem essas personagens. Nesse contínuo, também é narrada a concepção do segundo filho de Kehinde, o qual é fruto do vínculo amoroso entre ela e o português Alberto, já em momento posterior à conquista de sua alforria e da de seu filho primeiro. O personagem Alberto, por sua vez, pela ótica de Kehinde, é gradativamente caracterizado ao longo da narrativa como um homem de fraco caráter. Tal construção é tecida por meio de suas ações, conforme podemos acompanhar no fato de ele não assumir publicamente a relação com Kehinde. Na situação do segundo parto da narradora, a complicada configuração do relacionamento inter-racial aparece entrevista. Uma vez mais inscrevendo no repertório das imagens literárias a fertilidade da mulher negra, Kehinde conta: ${ }^{12}$

O Alberto estava apavorado, e até gostei quando ele perguntou se eu podia ficar sozinha enquanto ia à procura de uma aparadeira. Eu disse que sim, que me sentiria mais segura tendo uma aparadeira por perto, mas na verdade queria mesmo era me livrar dele, que estava me deixando nervosa. Ao contrário do nascimento do Banjokô, eu não gritei nem chorei; era como se aquele filho estivesse sendo puxado de dentro de mim por mãos muito habilidosas. Assim que fiquei sozinha e com mais liberdade para abrir as pernas e aliviar

\footnotetext{
${ }^{12}$ Todos os partos de Kehinde são descritos no romance e cada um deles é passível de ser lido como episódio que sintetiza as transformações da vida da narradora. Esse dado é muito significativo para essa genealogia de imagens da maternidade negra que evocamos.
} 
a pressão, senti a cabecinha querendo sair. Fiz um pouco de força e a carne perto da racha começou a se rasgar sem dor alguma. Eu me sentia leve e tranquila [...]. Comecei a sorrir e estava quase tendo meu filho sozinha naquele quarto vazio e estranho quando a Esméria voltou com alguns panos pendurados no ombro e um tacho de água quente. Ela nem teve tempo de perguntar pelo Alberto; apenas se agachou entre as minhas pernas e aparou meu filho, dizendo que era um menino, perfeitinho (Gonçalves, 2006, p. 398).

É possível apreender a força da narradora que praticamente dá a luz sozinha. A construção narrativa reforça, assim, o laço entre mãe e filho, cordão pulsante que alinhava todo o enredo da obra e também desvela a dificuldade da constituição das famílias negras. O sentimento de leveza e tranquilidade que ela afirma sentir, associado à ausência de Alberto, parece conter inversamente um prenúncio do que viria a ser, dez anos depois, a principal desgraça da vida de Kehinde: a venda de Omotunde, ${ }^{13}$ que nasce livre, como escravo, por seu próprio pai.

A consumação de Kehinde como mãe de Banjokô e Omotunde ${ }^{14}$ dá início a um breve período em que ela pode exercer sua maternidade e desfrutar de uma condição de vida mais estável, indo morar num sítio e estabelecendo sociedade com Alberto na administração de uma padaria. Contudo, a boa-venturança desse tempo é abreviada pelo processo de crise da relação amorosa, a qual tem fim a partir do anúncio do casamento entre Alberto e uma brasileira. De volta à cidade, num novo empenho de superação da conjuntura adversa, Kehinde e seus filhos passam a morar numa casa menor e os irmãos tornam-se cada vez mais cúmplices. É nesse ínterim que Kehinde sofre a perda do primeiro de seus filhos, Banjokô - aquele que por ser abiku já tinha sua passagem pela terra (Aye) prevista como rápida cumpre seu destino $(O d u)$ e se fere mortalmente com uma faca. Pode-se constatar que, no constructo interno ao romance, a morte do primeiro filho de Kehinde recebe uma explicação espiritual, que, contudo, não pode ser lida a despeito do contexto político

\footnotetext{
${ }^{13} \mathrm{O}$ filho de Kehinde recebe dois nomes, o africano Omotunde e o português Luiz. Tendo em vista a condição da narradora como africana liberta no Brasil, priorizaremos o nome africano (assim como o fazemos com a sua mãe). Omotunde Adeleke Danbiran: três nomes que têm como respectivos significados "a criança voltou", a criança será "mais poderosa que os inimigos" e uma homenagem aos voduns (em memória da avó), em especial à "Dan". Em outros trabalhos, detenho-me na referência que tais personagens fazem às figuras de Luiz Gama e Luísa Mahin, retomando a questão dos nomes.
}

${ }^{14}$ Dois abikus, isto é, “criança nascida para morrer” (Gonçalves, 2006, p. 19). 
brasileiro também encenado no texto, no qual se articulava uma rebelião escrava. Nessa direção, não deixa de ter força simbólica que a morte de Banjokô tenha sido concretizada por uma faca que deveria, ironicamente, munir os negros rebeldes contra os brancos senhores.

De modo distinto, Kehinde também perde o segundo filho. A perda de Omutende é estritamente relacionada à participação de Kehinde na rebelião escrava, na medida em que o desfecho trágico da ação instaura uma severa perseguição política aos africanos no Brasil, perseguição que, em última instância, impele a narradora a sair de Salvador, numa viagem que, depois, ganha contornos religiosos. Nessa situação, deixa a criança sob os cuidados das amigas e do pai, o qual, por sua vez, em desespero por dinheiro para sanar dívidas de jogo, vende o pequeno a um traficante de escravos.

Ao saber do ocorrido, três anos depois de sua partida, Kehinde, já iniciada como vodunci, volta a Salvador e tem início a busca que não cessará até a última página do livro. Ao poucos, ela vai encontrando pistas sobre o percurso de Omotunde e segue em seu encalço, passando por São Paulo e Rio de Janeiro. De volta à Bahia, sem sucesso em sua procura, ela entra em estado de tristeza aguda e, sob a influência de um sonho, em uma de suas idas ao cais na esperança de encontrar o filho, decide voltar à Àfrica. Retomando a proposição que tece a leitura seletiva que realizo neste artigo, por meio de tal recurso dá-se corpo à subjetividade da narradora, que é notoriamente marcada pela experiência da maternidade, correlacionada ao processo de constituição do Brasil enquanto nação.

Nesse sentido, ao iniciar sua viagem de retorno tendo a falta dos filhos como companhia, a experiência de Kehinde sinaliza o contexto que Manuela Carneiro da Cunha (2012) (citada na bibliografia do romance) bem analisou. De acordo com a antropóloga, os africanos libertos no Brasil, sobretudo após a revolta dos Malês, ${ }^{15}$ eram tidos como "apátridas", isto é, não tinham direitos de cidadãos e nem privilégios como estrangeiros. Indesejados por serem considerados um ameaça ao sistema escravista, na medida em que podiam criar

\footnotetext{
${ }^{15}$ As medidas drásticas pós-revolta dos Malês (deportação, taxa de 10 mil réis anuais, perseguições, impedimento de que esses africanos adquiram bens e anulação da legitimidade do que eles já possuíam) perduraram por 40 anos.
} 
alianças com os outros negros do país, foram de diversas maneiras forçados à imigração de volta à Áfica. ${ }^{16}$

A referência a esse dado histórico no constructo interno ao romance poderia explicar a facilidade que Kehinde encontra para seu regresso ao Daomé. As restrições e deportações da população africana liberta tinham, assim, estreita relação com as discussões sobre a formação do Brasil, as quais tiveram início após a independência. O recurso ideológico posto em ação para conferir legitimidade ao território reivindicado, segundo Cunha (2012), foi a ênfase em raízes imaginárias através da figura do indígena. Concebe-se assim como necessária uma nação homogênea, em que a população negra passa a ser um problema: “Seja como for, o que José Bonifácio silencia será no entanto dito em alto e bom som pelos antiescravagistas das décadas de 1830 e 1840: a homogeneidade necessária à existência da nação passava pela exclusão dos negros. Uma nação de livres, sim, mas de livres brancos" (Cunha, 2012, p. 110). ${ }^{17}$

Sendo assim, o retorno empreendido por Kehinde, em 1847, não lhe era uma experiência exclusiva. Em termos simbólicos, desenvolvendo minha tese, a passagem aponta para a constatação da impossibilidade do exercício pleno da maternidade negra em território brasileiro, dado que retoma os desenvolvimentos das proposições iniciais deste artigo, mas que não tem nessa assertiva o esgotamento de sua análise. Se acompanharmos essa segunda travessia de Kehinde, veremos que ela configura uma nova reviravolta do enredo, a qual ressignifica a narrativa. ${ }^{18}$

No barco, após ter conhecido e se envolvido amorosamente com o comerciante nascido em Serra Leoa, John - aquele que se compromete a seguir viagem, vender os produtos dela e retonar -, Kehinde desembarca, 26 dias depois, grávida. Por meio de uma rezadeira,

\footnotetext{
16 Cunha escreve: “Assim, os libertos africanos não eram evidentemente nem eleitores nem elegíveis, nem podiam fazer parte do Exército, Marinha ou Guarda Nacional, nem ingressar nas ordens religiosas. Em 1830, um decreto proibia aos forros e forras africanos, sob pena de prisão, a livre circulação fora de seu domicílio a não ser com passaporte de limitada vigência e que só deveria ser concedido mediante "exame da regularidade de sua conduta"' (Cunha, 2012, p. 99).

${ }^{17}$ A ideia antiescravista defendida por essa linha de pensamento implicava na abolição e exclusão dos negros do país, uma deportação progressiva, chegando-se pensar e especular a compra de um território na África para se fazer de colônia e campus de deportação. Angola, por exemplo, recusou tal proposta. De acordo com os indícios, afirma Cunha, foram sobretudo as precárias finanças do império que impediram a consecução de tão grandioso projeto (Cunha, 2012, p. 110).

${ }^{18} \mathrm{Na}$ primeira travessia, no tumbeiro, Kehinde embarca, em África, com a avó e a irmã, mas desembarca, no Brasil, sozinha.
} 
confirma, em seus primeiros dias em Uidá, o que já era uma intuição: "Não sei dizer como me senti, principalmente quando a rezadeira disse que eu era abençoada, pois seriam ibêjis. Eu queria apenas ter ficado alegre, muito alegre, mas de imediato muitas preocupações apareceram para roubar esse meu direito" (Gonçalves, 2006, p. 748). A notícia da gravidez surpreende o leitor e, uma vez mais, coloca em cena a potência da concepção de Kehinde lado a lado com a consciência das adversidades que se inscrevem como inerentes ao empreendimento de realizar-se como mãe.

Em consonância com isso, as preocupações quanto a seu futuro incerto substituem a alegria da notícia sobre os gêmeos, mas, no esforço de decidir levar a gestação adiante ou não, sua experiência pregressa de perda fala mais alto e, desafiando mais uma vez a lógica da interdição, decreta um "sim" como resposta ao dilema interno:

Uma das coisas que mais me ajudaram a decidir foi o seu sumiço, foi eu estar sozinha depois de já ter dado vida a dois filhos, foi medo de morrer sozinha, sem ter quem olhasse por mim ou fizesse uma serenata bonita em minha partida. Eu já não era tão nova, tinha trinta e sete anos, e talvez não surgisse outra oportunidade (Gonçalves, 2006, p. 748).

Poucas páginas depois da rememoração dessa decisão, a narradora, mantendo a reconstituição cronológica de sua trajetória, relata o terceiro parto que experienciou. $\mathrm{O}$ trecho, mais abreviado que na descrição dos partos anteriores, reinsere a participação fundamental dos orixás, na figura de Nanã, e da avó de Kehinde, assim como o pouco protagonismo do pai dos bebês no ato de seus nascimentos, de modo análogo aos partos de Omotunde e Banjokô. Em direção outra, porém, o sentido que é atribuído ao parto em terras africanas e, ademais, a reedição da experiência da mãe de Kehinde, que também gerou e deu à luz a gêmeas (Kehinde e Taiwo), parece indicar, então, um alinhamento do percurso da narradora à parcela de sua história fincada no passado africano, sublinhando a fertilidade como indício de força pessoal e expressão, pela lógica iorubana, daquilo que se concebe, em acordo com o que nos explica Ronilda Ribeiro (1995, p. 135), como a mais importante marca do vigor feminino, a saber, a maternidade.

Nessa direção, por um lado, a nova experiência de maternidade é vivida positivamente, e o processo de aleitamento, por exemplo, surge nessa etapa do romance circunscrito a um âmbito de liberdade e abundância: 
A Maria Clara e o João não saíam dos meus peitos, e todos diziam que assim era bom, que eles cresceriam melhor e mais depressa. Mas aquilo acabava comigo, que estava ficando quase tão magra quanto tinha sido a Aina, enquanto ela engordava, feliz com boa a vida que estava levando, apesar de trabalhar bastante (Gonçalves, 2006, p. 767).

Esse segmento da narrativa, que, como veremos, não se encerra simplesmente como consumação harmônica, é relevante porque, para além de afirmar a maternidade negra como realização possível, amplia a compreensão que se produz da trajetória da narradora, deslocando a experiência da escravização enquanto definidora estanque de tal percurso. A análise minuciosa do romance evidencia que a condição de africana em diáspora e, depois, de retornada de Kehinde é relatada de forma a tecer intrincadamente alguns dos dilemas de sua experiência.

Sinalizando isso, por outro lado, a narração do processo de ascensão social no novo território, que ocorre em coesão com a maternagem, está conectada ao procedimento de manter certa distância dos traços que a caracterizariam como pertencente a essa localidade. Desse modo, algumas de suas ações de afastamento da identidade africana indicam o reconhecimento por Kehinde da estrutura geopolítica daquele momento em que a identidade brasileira, ainda que evocando a marca da escravidão, conferia uma condição de privilégio aos que a possuíam em Uidá (e Lagos, para onde se muda depois). Passando pela escolha dos nomes dos filhos, Maria Clara e João, os valores que Kehinde adota na criação deles vão delineando uma experiência como mãe estruturada por configurações distintas daquelas que engendraram sua vivência no Brasil. A alteração de seu nome para Luísa Andrade da Silva (vinculado ao tratamento como "sinhá") pode ser lida como índice significativo de tal processo, o qual sustenta a complexidade da obra e conforma, em consonância com as necessidades de negociação de sua nacionalidade, o estatuto de estrangeira da narradora: no Brasil era africana e, agora, na África se colocava como brasileira.

A busca por um lugar para criar seus filhos realiza-se na África. $O$ que a trama narrativa do romance parece dizer é que somente nesse outro território e desde uma posição identitária complexa, o mecanismo de interdição à sua maternidade é neutralizado e ela consegue constituir família, tornando-se mãe e avó de muitos netos. Tal dado merece ênfase como contraposição à experiência negra brasileira e, a partir de uma 
leitura simbólica, pode ser interpretado como uma crítica aos modos como o discurso nacionalista brasileiro inseriu a mulher negra na literatura. Contudo, o desejo de encontrar o filho perdido mantém Kehinde ligada ao Brasil. Essa ambivalência sublinha sua inquietação e o sentimento de falta que lhe constitui. Inverte-se, assim, a mirada da narradora que, agora, olha para o outro lado do oceano, em direção ao Brasil, na busca pelo filho, na esperança de uma realização que, porém, o romance findará sem poder concretizar. A potência de conexão entre o século XIX e XXI contida nesse olhar inquieto permanece aguda e lança sobre a literatura concebida como nacional importantes problematizações. A interface entre literatura e sociedade transfigurada em Um defeito de cor remete a um desconforto sinalizado por outros sujeitos que se juntam em coletivo a Kehinde para questionar qual o lugar que lhes cabe no território chamado Brasil.

\section{O Brasil como pergunta na literatura negra}

O enredo de Um defeito de cor cria, assim, uma relação viva entre Brasil e África e, se quisermos ser mais específicos, entre a emergente nação Brasil e o reino do Daomé. Por meio da divisão da narradora Kehinde no que diz respeito, sobretudo, a seu filho Omotunde, cria-se uma vinculação inquestionável entre uma ascendência africana e uma descendência brasileira, sendo que esta, conforme o romance parece propor, infelizmente, não vinga, como Banjokô, ou permanece, como Omotunde, invisibilizada (desaparecida). É nesse movimento complexo, que precisou ser analiticamente explicitado aqui, que o romance se encontra com as proposições de Conceição Evaristo apresentadas no primeiro segmento deste artigo. Em atuação que sublinha a matriz africana da sociedade brasileira e dá a ver o estatuto complexo e ideologicamente orientado com que tal repertório foi incorporado pela intelectualidade (branca) do país, Evaristo formula um questionamento que é fundamental para a reflexão que estamos tecendo:

O que se argumenta aqui é o que essa falta de representação materna para a mulher negra na literatura brasileira pode significar. Estaria a literatura, assim como a história, produzindo um apagamento ou destacando determinados aspectos em detrimento de outros, e assim ocultando os sentidos de uma matriz africana na sociedade brasileira? (Evaristo, 2005, p. 3). 
A essa deixa reflexiva Um defeito de cor parece responder enquanto transfiguração estética do problema. A obra coloca em primeiro plano o procedimento que foi anteriormente apontado como motor para o funcionamento do mito da "mãe preta", a saber, a subtração da criança negra, o filho, do campo discursivo da literatura e da crítica. Contudo, em Um defeito de cor, essa subtração, além de ser visibilizada, é problematizada, é chorada, é sentida e, acima de tudo, não é dada como um fato consumado. A última travessia de Kehinde em direção ao Brasil expressa a não desistência dela em encontrar o filho e poderia ser lida, assim, como um devir do reconhecimento dessa ascendência africana sublinhada por Evaristo.

Ao analisar a polêmica ocorrida em torno da denúncia de conteúdo racista na obra de Monteiro Lobato, ${ }^{19}$ o crítico Marcos Natali (2016) também vai ao encontro dessa hipótese de leitura de Um defeito de cor, visto que coloca o infanticídio (da criança negra) simbolicamente operado na discursividade nacionalista - efetivamente pelas forças opressoras do estado (como a polícia) - como elemento central da reflexão crítica. Em sua abordagem do debate, constituinte do capítulo de sua tese de livre docência intitulada "Uma segunda Esméria: do amor à literatura (e ao escravo) (sobre Monteiro Lobato)", Natali (2016) elabora, entre outras proposições potentes, a ideia de que na reação negativa de parte da crítica e intelectualidade do país à denúncia estava presente a reivindicação da leitura da obra de Lobato (e da literatura em geral) como forma de adesão a uma narrativa particular da história nacional e da tradição literária. Esse procedimento, como apontou Ana Maria Gonçalves (2010) em comentário à mesma polêmica, retirou a centralidade da preocupação com a criança negra, que estaria vulnerável aos conteúdos de depreciação da mulher negra nas situações de leitura da obra de Lobato em sala de aula, em prol de uma discussão sobre a autonomia da literatura (o alarde da "censura" foi mobilizado pelos que reagiram contra a denúncia) que focalizou a experiência de liberdade centrada nos sujeitos brancos, os quais não constituem alvo da violência do racismo. ${ }^{20}$ Natali recupera essa indicação e mostra como a

\footnotetext{
${ }^{19}$ A polêmica surge a partir de uma queixa protocolada no Conselho Nacional de Educação, em 2010, por Antonio Gomes Costa Neto, que aponta a presença de conteúdo racista na obra de Lobato e, sobretudo, nas descrições da Tia Nastácia presentes no livro Caçadas de Pedrinho, publicado em 1933.

${ }^{20}$ Depois de explicitar os vínculos entre Lobato e o projeto eugenista de eliminação da população negra do país, Gonçalves (2010) dirige-se ao leitor e pede o seu deslocamento do lugar de
} 
subtração da criança negra do campo simbólico justifica-se na evocação, sob o lastro de "um direito à construção retrospectiva da experiência familiar e histórica sob a luz do afeto", da nostalgia do escravo e, em especial, da "mãe preta" (2016, p. 181).

Nessa direção, Natali expõe como os argumentos formulados publicamente no debate permitiram ver que parte do giro ideológico analisado aqui nas incorporações da figura da "mãe preta" no final do século XIX e início do século XX, segue vexatoriamente presente nas formulações do século XXI. É isso o que verificamos no depoimento de Leyla Perrone-Moisés à Academia Brasileira de Letras, em 2005, citado pelo crítico:

Todo autor de biografia tende a começar pela infância. Na autobiografia intelectual, necessariamente, são os primeiros livros, as primeiras leituras. O primeiro livro que li na minha vida, aos cinco anos, se chamava Rosa Maria no Reino Encantado, de Érico Veríssimo. [...] Logo em seguida, passei para Monteiro Lobato. Sobre isso, vou dizer algumas coisas porque, se não são importantes, pelo menos formam uma figura. Passei a minha infância numa cidadezinha de Minas Gerais, Passa-Quatro, num vale da serra da Mantiqueira [...]. Em casa, tínhamos um quintal muito grande, com muitas árvores frutíferas, e levávamos uma vida quase que de sítio. Então li Monteiro Lobato num contexto de Sítio do Pica-Pau Amarelo, porque lia seus livros em cima de uma árvore, uma amoreira que eu considerava minha. Subia, sentava-me num galho lá em cima, e assim li todo o Monteiro Lobato. Não havia o Rabicó, mas havia as galinhas etc. E eu tinha uma tia Anastácia, porque a cozinheira era uma negra muito escura que, de um modo politicamente incorreto, tinha o apelido de Vavão. Era como nós, crianças, pronunciávamos "carvão". Mas acho que foi ela mesma que se auto-apelidou Vavão (Perrone- Moisés, 2005 apud Natali, 2016, p. 335).

A citação prescinde de comentários. Contudo, Natali segue no desenvolvimento de sua análise e escreve:

É como se a cena descrita em seu depoimento memorialístico, com tudo aquilo que ela reverbera, em particular a localização da introdução à leitura no espaço doméstico da família e do privilégio, fosse uma espécie de patrimônio nacional a ser generalizado. É como se o ingresso no mundo das letras tivesse

privilégio que a branquitude instaura: "Peço agora que você faça um exercício: imagine uma criança na sala de aula das escolas públicas de ensino médio e fundamental no Brasil. Negra." 
que ser o recebimento de uma herança que inclui a naturalização de certa visão de mundo, como se a própria existência da cultura nacional dependesse da capacidade de preservar o que há nessa cena original de confluência entre literatura e poder. É como se, ainda, "Perpetuar isso [fosse] patriótico, esse racismo que 'faz parte do patrimônio cultural de todos nós'", como escreveu a romancista Ana Maria Gonçalves citando carta pública assinada por vários autores da literatura infantil brasileira. É claro que é possível que seja exatamente isso mesmo o patriotismo (brasileiro ou não) e que ele não possa sobreviver sem esse conjunto de gestos excludentes e discriminatórios, e neste caso os signatários estariam equivocados não na percepção de que as críticas são uma ameaça à ideia de país, mas apenas na negação do aspecto violento do nacionalismo (Natali, 2016, p. 164).

Acompanhamos, portanto, a construção de um argumento afiado que, reconhecendo a negação do direito da maternidade à mulher negra (o texto de Natali não deixa dúvidas quanto ao vínculo entre o desaparecimento da criança negra e a representação maternal da mulher negra), chega ao mesmo ponto sugerido por Conceição Evaristo (2005) no início desta seção: o questionamento da rede discursiva do nacionalismo brasileiro. Subjacente à reação inconformada de parte da crítica ao indicativo do órgão estatal de reconhecer a necessidade de mediação do conteúdo racista presente no livro de Lobato, atualizou-se um intrincado mecanismo ideológico, segundo o qual, de acordo com Natali (2016), a literatura é concebida como um "gênero blindado", isto é, imune a questionamentos éticos e resistente a avaliações morais e políticas. Nesse processo, em defesa da "liberdade de expressão" e da irredutibilidade da literatura a "um mero" instrumento pedagógico, vinculou-se a obra literária à narrativa nacionalista do país como forma de garantia e segurança da perspectiva da história expressa por esses sujeitos críticos (brancos).

O não reconhecimento da "violência do nacionalismo", que, em última instância, exclui ou subalterniza os negros e negras do campo entendido como coletivo, perfaz um novo gesto de violência, o qual demonstra a incapacidade dos agentes desta ação colocarem-se no lugar do outro (a despeito do pedido de Ana Maria Gonçalves e dos avanços no que tange à discussão sobre o racismo no país). Por isso, escreve Natali: 
Dado o assunto em pauta, o gesto que exclui a possibilidade da leitura dissonante - má fé e ignorância sendo as únicas explicações possíveis para a discordância - acaba tendo como resultado a interdição da verbalização das formas e das consequências do racismo na tradição cultural nacional, como se a simples expressão de contrariedade fosse a traição de um pacto antigo, talvez o pacto da própria formação da nação: o elemento negro (uma personagem, por exemplo) será assimilado pela cultura nacional e será parte de sua autorrepresentação, porém sempre de maneira subalterna. A possibilidade da suavidade dessa absorção é a própria imagem que se faz da nação (sua face oculta é a hostilidade que emerge quando o afeto é recusado) (2016, p. 178-179).

De modo contundente, ele define, portanto, a literatura, assim como a crítica, como agentes de opressão no que se refere ao racismo estrutural brasileiro. A pergunta que recupera a trama do romance Amada, de Toni Morrison, e encerra o capítulo - "O que mudaria se pensássemos nessa cena, a de um infanticídio, cometido com a finalidade de proteger a filha da instituição legal da escravidão, como o momento de fundação do país?" (Natali, 2016, p. 194) - vincula a fundação da nação ao procedimento simbólico que apresentamos ao longo deste artigo e que acredito ter em Um defeito de cor um gesto de problematização.

Ao apresentar a relação entre mãe e filho negros como núcleo estruturante de seu romance, Ana Maria Gonçalves, autora que se enuncia como negra, permite que se visibilize esse emaranhado ideológico e reafirma a participação da literatura na disputa pelo que se compreende como Brasil, reapropriando-se a partir de um âmbito de interesses comprometido com a experiência sensível das comunidades negras nesse território. Esse gesto torna-se ainda mais explícito se a análise do romance for remetida de modo comparatista a outras narrativas historiográficas e literárias, sobretudo na contraposição com a figura da "mãe preta". A polêmica contemporânea em torno da representação da Tia Nastácia e as considerações críticas de Natali sobre ela somam-se assim aos desenvolvimentos analíticos operados neste artigo e reforçam a compreensão da relevância da forma como a maternidade é representada em Um defeito de cor para a discussão sobre o nacionalismo no Brasil.

Recuando em direção ao passado, constata-se como em diversos momentos históricos a ideia da mãe negra submissa ao sofrimento e carinhosa para com a prole de seus escravizadores vem sendo 
atualizada e como uma produção simbólica que tem início no século XIX foi responsável pela elaboração dessa imagem sem que a violência inerente à subtração dos filhos negros da relação com essas mulheres fosse nela problematizada. Nesse sentido, explica-se o fato de que entre as produções que compreendem o que as historiografias literárias definiram como período de formação nacional encontremos as obras de José de Alencar e, nesse conjunto, a título de precioso exemplo, a peça Mãe, publicada entre 1859-1860 no Rio de Janeiro. Nela, a escrava Joana protagoniza o drama como uma mãe que, a fim de proteger o filho, Jorge, do estigma da escravidão (a história se passa em 1855), omite deste a relação biológica entre ambos e declara-se sua ama de leite, isto é, sua "mãe preta". A perversa trama da peça leva Jorge a descobrir a verdadeira identidade da mãe, que, contudo, na tentativa de resguardar a imagem social do filho, recusa-se até o seu derradeiro momento de vida, o pedido que este lhe implora ("Eu sou teu filho!... Dize!... Uma vez ao menos... este nome") e morre negando a maternidade. ${ }^{21} \mathrm{O}$ amor sublime materno que "até mesmo uma escrava pode sentir" é representado como contíguo ao martírio pelo qual passa a escrava que, por meio dessa atitude, converte-se (desde a dimensão pedagógica da peça) em exemplo. ${ }^{22}$ Publicado no mesmo ano, porém tendo permanecido na invisibilidade, encontramos o trabalho de Maria Firmina dos Reis. Com uma representação da maternidade negra contundentemente contrária a essa, em seu romance Ursúla (1859), o relato da personagem Mãe Susana expõe a dor da separação entre mãe e filha motivada pelo tráfico escravista, assim como, em 1887, essa mesma autora concebe uma outra personagem, coincidentemente Joana, que no conto "A escrava", de modo dramático e nada heroico, também declara o sofrimento de uma mãe de descendência africana que se vê apartada de seus filhos no Brasil. Ao contrário da personagem de Alencar, que morre sem pode dizer-se mãe e tem nesse gesto uma celebração, as contemporâneas personagens de Firmina dos Reis afirmam sua

\footnotetext{
${ }^{21}$ Acompanhamos nos diálogos finais da peça: "JORGE - Eu sou teu filho!... Dize!... Uma vez ao menos... este nome. / JOANA - Ah!... Não!... Não posso! / JORGE - Fala! Fala! / JOANA - É um atrevimento!... Mas eu queria antes de morrer... beijar sua... sua testa, meu nhonhô!... / JORGE Mãe!... / JOANA - Ah!... Joana morre feliz! / JORGE - Abandonando seu filho. / JOANA Nhonhô!... Ele se enganou!... Eu não... Eu não sou tua mãe, não... meu filho! (Morre.) / JORGE (de joelhos) - Minha mãe!..." (Alencar, 1922).

${ }^{22}$ Seguimos aqui a análise da peça realizada por Maria Elizabeth Ribeiro Carneiro (2006) em "Imagens de 'mães pretas': representações da maternidade e da escravidão na escrita de José de Alencar”.
} 
maternidade, circunscritas à violência. Em detrimento dessas obras e de seu potencial crítico, é o trabalho de Alencar (a despeito de qualquer consideração ética que mencione o público posicionamento favorável à escravidão desse autor) que passou a figurar como referência significativa do cânone comprometido com o projeto de formação nacional. $\mathrm{O}$ panorama que vislumbramos nessa ponte entre presente $\mathrm{e}$ passado evidencia uma ideologia em entranhado funcionamento.

A tensão que Um defeito de cor estabelece com o discurso nacionalista pode ser vinculada à linhagem que tem início com o trabalho de Firmina dos Reis e que hoje compõe um conjunto de obras que se projeta como literatura negra e/ou afro-brasileira. O debate em torno desses conceitos é rico e repleto de nuances e pressupostos de acentuada relevância na discussão sobre o âmbito literário do Brasil. Para além de definições conclusivas, porém, deve-se reconhecer e alimentar a necessidade dessa reflexão e aproximar-se dos textos literários, conforme escreve Maria Nazareth Soares Fonseca (2011), percebendo o agenciamento que cada um deles estabelece entre a linguagem e o combate ao racismo e à invisibilização do negro:

é pertinente auscultar o texto e perceber os sentidos que ele ajuda a construir na contramão, nos caminhos marginais, mas por isso mesmo, menos percorridos por parafernália teórica [...] mais que se prender a conceituações, importa possibilitar a entrada dos textos em maior circulação, aprendê-los em sua feitura, discutir a materialidade discursiva com que se apresentam, assumindo as inovações de sua escrita. Vários escritos têm realizado a façanha de imprimir o político nos arranjos do texto que prefere se desligar da encenação do protesto explícito (Fonseca, 2011, p. 269).

Nesse sentido, e ainda em consonância com as proposições de Fonseca (2011), a análise da representação da maternidade negra em Um defeito de cor sinaliza como essa obra instaura, por meio de sua linguagem, um espaço de produtivo trânsito entre os discursos que conformam o que se entende como Brasil e, especialmente, sobre a relevância da mulher negra e da ascendência africana na construção desse espaço. O livro parece corroborar a necessidade de que se afirme, como o fez Cuti, que o "Brasil é dos brasileiros, porém é preciso acrescentar que é de todos os brasileiros". Tal demanda reitera o fato de que a "palavra 'Brasil", segundo Cuti, "esconde crimes e criminosos". E "é com versões como 
essas que se foi constituindo uma formação discursiva, um jeito coletivo de encarar os fatos no tocante à questão racial" (Cuti, 2010, p. 11).

A insistência por parte do corpo crítico analisado por Natali (2010) de que a literatura seria uma entidade, a priori, comprometida com o senso crítico e com o melhoramento humano, assim como a noção de Brasil como entidade coesa e harmônica (lugar da democracia racial), revela-se, no embate com o contradiscurso negro, ideológica (no sentido clássico de uma das acepções de ideologia, isto é, uma noção particular que se generaliza como universal) e tem na e pela literatura um campo de disputa. Nas palavras de Cuti:

Certa mordaça em torno da questão racial brasileira vem sendo rasgada por seguidas gerações, mas sua fibra é forte, tecida nas instâncias do poder, e a literatura é um dos seus fios que mais oferece resistência, pois, quando vibra, ainda entoa loas às ilusões de hierarquias congênitas para continuar alimentando, com seu veneno, o imaginário coletivo de todos os que dela se alimentam direta ou indiretamente. A literatura, pois, precisa de forte antídoto contra o racismo nela entranhado (2010, p. 13).

Considerando a acepção de literatura que surge de uma apropriação dela por parte dos negros e negras, ou seja, "antídoto" contra o "veneno" nela mesmo "entranhado", Cuti tem uma produção teórica e literária significativa que dialoga com a crítica que veio à tona na polêmica sobre Lobato e numa análise sobre os termos "literatura brasileira", "afro-brasileira" e "negro-brasileira" mobiliza de modo agudo a discussão em torno da identidade nacional:

A nostalgia da origem que surpreendeu os africanos quando recémchegados ao Brasil dissolveu-se gradativamente nos embates da sobrevivência, em todos os níveis, inclusive o cultural. Como cultura não tem cor, acostumou-se a falar da "contribuição do negro para a cultura brasileira". A ideia de "brasileiro" sem "negro" nos remete ao racismo do século XIX, traduzido pelos ideólogos brasileiros como um desaparecimento do negro pela miscigenação. Brasileiro, então, para aqueles ideólogos passou a ser sinônimo de não negro, ou seja, o espectro branco para o qual toda "contribuição" negra e indígena deve convergir (Cuti, 2010, p. 42).

O núcleo do argumento de Cuti é, pois, a consciência de que a produção literária enquadrada como negra, no Brasil, relaciona-se a uma experiência particular de enfrentamento do racismo, que o 
termo "brasileiro" não contempla - ao contrário solapa via ideologia da branquitude (segundo ele, abrindo senda para o debate que mencionamos, o termo afro-brasileiro também não dá conta dessa experiência, já que nem todo afro-brasileiro é necessariamente - e isso significa fenotipicamente - negro).

O conjunto de obras reconhecidas como negro-brasileiras por Cuti (muitas delas presentes também na delimitação de Eduardo de Assis Duarte) referem-se, como ele afirma, a uma singularidade negra e ao mesmo tempo brasileira, inclusive em termos linguísticos, já que, ao contrário de outras nações africanas, assumiu-se aqui a língua portuguesa como matriz desses discursos. O tom da pele somado à assertividade negra por parte da autoria dos textos literários teriam como efeito a validação da identidade negra na disputa do Brasil como nação diaspórica. Desafiando o silêncio e as lacunas da literatura canônica, o termo "negro", segundo Cuti, constitui-se, assim, como um signo ameaçador que tem entre seus objetivos o de:

revelar o que o Brasil esconde de si mesmo pela ação do racismo do qual a cultura nacional está impregnada, como também alertar para o como a reação escrita de uma subjetividade subjugada redundou e redunda na prática de formas que atendam não ao chamado de uma herança africana, mas à necessidade de uma ruptura com o processo de alienação que o racismo provoca (Cuti, 2010, p. 46).

Talvez em sentido mais profundo que o termo "negro", a assunção de uma "maternidade negra" e com ela o reconhecimento e valoração dessa matriz africana do Brasil, ainda se constitui ameaçadora e tem no diálogo que Um defeito de cor pode promover com o cânone literário e com o seu suplemento negro um mecanismo de, respectivamente, contestação e afirmação. Ana Maria Gonçalves declarou publicamente que se entendeu como negra a partir da escrita do livro; ${ }^{23}$ mais do que

${ }^{23}$ No que se refere a isso, o cotejamento entre esse romance e a primeira obra, de caráter autobiográfico, publicada por Gonçalves, a saber, Ao lado e à margem do que sentes por mim, permite que vislumbremos a diferença entre essas construções de identidade. No primeiro livro, ao descrever uma situação de infância em que, na cidade do interior mineiro em que nasceu, Ibiá, uma criança branca, durante a preparação para um festejo religioso, afirma que a narradora "Ana" não pode representar uma santa por ser "quase preta", essa narradora afirma-se "morena". Segue o trecho: "A Elzinha, do alto de sua loirice, de dentro de sua pele clara, feito santa de porcelana, fixou em mim os olhos azuis de Nossa Senhora e disparou: - Quem é que já viu Nossa Senhora quase preta?! Tem graça.... Não tinha graça nenhuma. Uma raiva imensa fez com que eu desatasse a chorar e nem conseguisse dizer que não era preta, que era apenas morena. E que tinha os olhos verdes, e que ao nascer eles eram azuis" (Gonçalves, 2002). 
isso, em conversa no evento "Melanina Acentuada", ocorrido em Salvador, em 2016, ela afirmou que a pesquisa realizada para a escrita da obra permitiu a elaboração da história a que ela não teve acesso em sua formação. Em consonância com Cuti (2010), então, pode-se entender a obra como um constructo via elaboração ficcional desse Brasil que se esconde de si mesmo. Conforme buscamos evidenciar, a construção formal do enredo da obra tem na representação da maternidade forte potência semântica, que é disruptiva do que se entende como nacional, apontando para as estratégias de opressão e subtração dos elementos negros como fundamento ideológico dessa discursividade. O livro fazse assim terra fértil de onde surgem questões caras ao contemporâneo.

\section{Referências}

ALENCAR, José de (1922). Mãe. Drama em quatro actos. Introdução de Mário de Alencar. Rio de Janeiro: Garnier. (Collecção Áurea)

BERND, Zilá (2012). Em busca dos rastros perdidos da memória ancestral: um estudo de Um defeito de cor, de Ana Maria Gonçalves. Estudos de literatura brasileira contemporânea, Brasília, n. 40, p. 29-42, jul./dez.

CARNEIRO, Maria Elizabeth Ribeiro (2006). Imagens de "mães pretas": representações da maternidade e da escravidão na escrita de José de Alencar. Revista Unimontes Científica, Montes Claros, v. 8, n. 2, jul./dez.

CORTÊS, Felipe Ribeiro de Araujo (2010). Viver na fronteira: a consciência da intelectual diaspórica em Um defeito de cor, de Ana Maria Gonçalves. Dissertação (Mestrado em Letras - Estudos Literários) - Universidade Federal de Minas Gerais, Belo Horizonte.

CUNHA, Manuela Carneiro da (2012). Negros, estrangeiros: os escravos libertos e sua volta à África. São Paulo: Companhia das Letras.

CUTI, Luis Silva (2010). Literatura negro-brasileira. São Paulo: Selo Negro.

DAVIS, Angela (2016). Mulheres, raça e classe. São Paulo: Boitempo.

DEIAB, Rafaela de Andrade (2006). A mãe-preta na literatura brasileira: a ambiguidade como construção social (1880-1950). Dissertação (Mestrado em Antropologia Social) - Universidade de São Paulo, São Paulo.

DUARTE, Eduardo de Assis (2009). Mulheres marcadas: literatura, gênero e etnicidade. Terra roxa e outras terras: Revista de estudos literários, Londrina, v. 17, n. 1, dez. 
DUARTE, Eduardo de Assis (2009). Na cartografia do romance brasileiro: Um defeito de cor, de Ana Maria Gonçalves. In: TORNQUIST, Carmen Susana et al. (Org.). Leituras da resistência: corpo, violência e poder. Florianópolis: Editora Mulheres, 2009. Disponível em: < https://goo.gl/8yo44r>. Acesso em: 12 jan. 2016 EVARISTO, Conceição (2005). Gênero e etnia: uma escre(vivência) de dupla face. In: MOREIRA, Nadilza Martins de Barros; SCHNEIDER, Liane (Org.). Mulheres no mundo: etnia, marginalidade e diáspora. João Pessoa: Editora da UFPB; Idéia.

FIGUEIREDO, Eurídice (2009). Os brasileiros retornados à África. Cadernos de Letras da UFF, Niterói, n. 38, p. 51-70.

FONSECA, Maria Nazareth (2011). Literatura negra: os sentidos e as ramificações. In: DUARTE, Eduardo de Assis Duarte; FONSECA, Maria Nazareth Soares (Org.). Literatura e afro-descendência no Brasil: história teoria e polêmica. Belo Horizonte: Editora da UFMG. v. 4.

GONÇALVES, Aline Najara da Silva (2010). Luiza Mahin entre a ficção e a história. Dissertação (Mestrado em Estudo de Linguagens) - Universidade do Estado da Bahia, Salvador.

GONÇALVES, Ana Maria (2002). Ao lado e à margem do que sentes por mim. Salvador: Borboletras.

GONÇALVES, Ana Maria (2006). Um defeito de cor. São Paulo: Record.

GONÇALVES, Ana Maria (2010). Lobato: não é sobre você que devemos falar. Geledés, 22 nov. On-line. Disponível em: <https://goo.gl/zpRctA>. Acesso em: 12 jan. 2016.

GONZALEZ, Lélia (1984). Racismo e sexismo na cultura brasileira. Revista Ciências Sociais Hoje, São Paulo, p. 223-244.

LANGE, Mariana de Bastiane (2008). Vicissitudes da memória: destino, desvio e(m) Um defeito de cor. Dissertação (Mestrado em Letras) - Universidade Federal de Santa Catarina, Florianópolis.

NATALI, Marcos P. (2016). A literatura em questão. Tese (Livre-docência) Universidade de São Paulo, São Paulo.

REIS, Maria Firmina dos (2017). Úrsula: romance. Belo Horizonte: Editora da PUC Minas.

RIBEIRO, Ronilda (1995). Mãe negra, o significado iorubá da maternidade. Tese (Doutorado em Antropologia Social) - Universidade de São Paulo, São Paulo. 
RONCADOR, Sonia (2008). O mito da mãe preta no imaginário literário de raça e mestiçagem cultural. Estudos de Literatura Brasileira Contemporânea, Brasília, n. 31, p. 129-152, jan./jun.

VASCONCELOS, Vania Maria Ferreira de (2014). No colo das iabás: raça e gênero em escritoras afro-brasileiras contemporâneas. Tese (Doutorado em Literatura) Universidade de Brasília, Brasília.

WALLACE-SANDERS, Kimberly (2008). Mammy: a century of race, gender, and Southern memory. Ann Arbor: University of Michigan Press.

Recebido em 30 de maio de 2017.

Aprovado em 4 de novembro de 2017.

\section{resumo/abstract/resumen}

\section{Maternidade negra em Um defeito de cor: a representação literária como disrupção do nacionalismo}

Fabiana Carneiro da Silva

Ao se configurar fundamentalmente como o relato (carta) de uma mãe negra ao filho desaparecido, o romance Um defeito de cor, publicado por Ana Maria Gonçalves em 2006, incita-nos a adentrar de modo detido no conjunto de questões pertinentes à representação da maternidade da mulher negra na literatura produzida no Brasil. Desse modo, neste artigo, recupero criticamente o estereótipo da "mãe preta" para analisar como Um defeito de cor o desconstrói e inscreve em nossa literatura uma experiência complexa de maternidade negra, a qual, de modo particular, é disruptiva em relação ao discurso nacionalista brasileiro, revelando sua dimensão ideológica e racista.

Palavras-chave: Um defeito de cor, Ana Maria Gonçalves, maternidade negra, "mãe preta", teoria literária.

\section{Black motherhood in Um defeito de cor: literary representation as disruption of nationalism}

Fabiana Carneiro da Silva

Written as letter of a black mother to her disappeared child, the novel Um defeito de cor, by Ana Maria Gonçalves (2006), urges us to reflect about the representation of black motherhood in Brazilian literature. In this article, I critically recover the stereotype of the "mãe preta" to analyze how Um defeito de cor deconstructs and literarily inscribes a complex experience of black 
motherhood that is disruptive to Brazil's nationalist discourse in that it reveals its ideological and racist dimension.

Keywords: Um defeito de cor, Ana Maria Gonçalves, black motherhood, "mãe preta", literary theory.

\section{Maternidad negra en Um defeito de cor: la representación literaria como disrupción del nacionalismo}

Fabiana Carneiro da Silva

Al configurarse fundamentalmente como el relato (carta) de una madre negra al hijo desaparecido, la novela Um defeito de cor, publicada em 2006 por Ana Maria Gonçalves, incita a adentrarnos de modo detenido en el conjunto de cuestiones pertinentes a la representación de la maternidad de la mujer negra en la literatura producida en Brasil. De este modo, en este artículo, recupero críticamente el estereotipo de la "madre negra" para analizar cómo Um defeito de cor lo deconstruye e inscribe en nuestra literatura una experiencia compleja de la maternidad negra, la cual, de modo particular, es disruptiva en relación al discurso nacionalista brasileño, revelando su dimensión ideológica y racista.

Palabras clave: Um defeito de cor, Ana Maria Gonçalves, maternidad negra, "mãe preta", teoría literaria. 